\title{
Tracking an invasive honey bee pest: mitochondrial DNA variation in North American small hive beetles
}

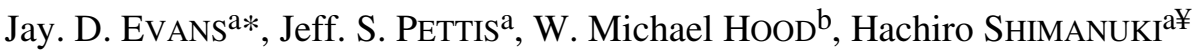 \\ ${ }^{a}$ USDA-ARS Bee Research Lab, Bldg. 476 BARC-E, Beltsville, MD 20705, USA \\ b Department of Entomology, Clemson University, Clemson, SC 29634, USA
}

(Received 14 August 2001; revised 15 May 2002; accepted 12 August 2002)

\begin{abstract}
We describe the current and past distributions of North American small hive beetles (Aethina tumida) having two distinct mitochondrial DNA haplotypes. A collection of 539 hive beetles showed irregular distributions of these haplotypes across the southeastern US. Beetles from the first collections made in coastal South Carolina showed haplotype NA1, exclusively. This haplotype is less common in Georgia and was not observed in North Carolina. Later collections from this and other parts of South Carolina appear more similar to those found in other states. The body size of beetles was not correlated with their haplotype, suggesting that differences in haplotype frequency do not reflect selection pressures on covarying differences in the genomes of these beetles. We discuss the implications for inferring the number of separate hive beetle introductions to the US, and for estimating the migration dynamics by hive beetles as they expand their ranges in the New World.
\end{abstract}

Apis mellifera / mtDNA / invasive pest / Nitidulidae / Aethina tumida

\section{INTRODUCTION}

Honey bees (Apis mellifera L.) suffer from a diversity of parasites and pathogens. Unfortunately, many of these pests have crossed international borders repeatedly, arguably as a consequence of international trade in bees and hive products. The small hive beetle, Aethina tumida Murray (Coleoptera: Nitidulidae), is the latest serious honey bee pest to arrive in the United States (Elzen et al., 1999; Hood, 2000; Pettis and Shimanuki, 2000). This species is a minor pest to beekeepers in Africa, where it inhabits colonies of several honey bee subspecies (Buys, 1975; Roberts, 1979). Nevertheless, small hive beetles (SHB) have had an economic impact in the US, both through colony losses and the contamination of stored hive products (Pettis and Shimanuki, 2000). While the long-term impacts of SHB on North American bees are unclear, the rapid spread of this species throughout the United States suggests that it will remain a significant threat for beekeepers.

SHB were first identified from the US port city of Charleston, South Carolina, in the summer of 1996 (Hood, 2000). Subsequently, SHB were confirmed in the states of Florida and Georgia (1998), and North Carolina (1998; anecdotal evidence suggests that hive beetles were present as early as 1996 in Georgia, M. Hood, unpublished data). As of April, 2002, SHB had been found in 25 states in the US

\footnotetext{
* Correspondence and reprints

E-mail: evansj@ba.ars.usda.gov

$¥$ : retired
} 
(J. Pettis, unpublished data), although collections from several of these states are limited to interceptions of beetles from colonies or worker packages recently transported from the southeastern US. For example, adult beetles have been identified in Minnesota and Iowa, although SHB are not yet broadly established in these states. Nevertheless, established beetle populations in states such as Ohio $(1500 \mathrm{~km}$ North from Florida) indicate a potential for SHB to colonize much of North America. Additionally, the annual spring movement of honey bee colonies from South to North provides an avenue for the continued spread of SHB into northern regions of North America.

In this paper, we use variation at the mitochondrial cytochrome oxidase I (COI) gene to describe populations of hive beetles. Mitochondrial DNA (mtDNA) variation is often used to classify insect species. As one example, much of our genetic knowledge of racial differences in honey bees stems from studies of mtDNA variation (Sheppard et al., 1999). MtDNA sequences also can be used to identify and characterize honey bee pests, including Varroa mites (de Guzman and Rinderer, 1999; Anderson and Trueman, 2000). DNA sequences from the COI gene have been used to show a close relationship between hive beetles collected in the United States and hive beetles collected from South Africa (Evans et al., 2000). In fact, two distinct haplotypes found in the US (NA1 and NA2) were as distinct from each other as they were from most haplotypes found in South Africa. These results, alongside morphological and field studies (Elzen et al., 1999), provide strong evidence that hive beetles now in the US are derived from southern African populations, and that biological data collected in South Africa will be relevant to beetle populations in North America.

The mtDNA analyses conducted by Evans et al. (2000) indicated an irregular distribution of haplotypes across beetle samples collected in four states in the US. Haplotype NA1 predominated in South Carolina samples, while samples from Georgia and Florida showed biases toward haplotype NA2, and those from North Carolina showed this haplotype exclusively.

We explore SHB genetic variation in the present paper and address four hypotheses that might explain differences in haplotypes across states in the US: (1) State-to-state differences represent a signal of two or more distinct introductions of hive beetles into the US, (2) differences across states reflect 'founder' effects, whereby small numbers of female beetles were transported into new sites, giving these sites a biased haplotype frequency, (3) these haplotypes are associated with genes that are under strong selection in different regions, and (4) haplotype variation is random across states and the observed differences reflect sampling bias (e.g., Funk, 1999). We also present more extensive DNA sequence data from beetles collected in their putative native range.

\section{MATERIALS AND METHODS}

\subsection{Collection of samples and DNA isolation}

We analyzed a total of 539 hive beetles collected from 26 apiaries in Florida, Georgia, South Carolina, and North Carolina (Tab. I) between 1996 and 2000. South Carolina beetles were collected in 19962000, while beetles from Georgia and Florida were collected in two years only (1998 and 2000 for Georgia, 1998 and 1999 for Florida). Beetles from North Carolina were collected in 1998, only. To better understand genetic variation of hive beetles from their putative source populations, we analyzed a total of nine beetles collected from three sites in Zimbabwe. These sequences were compared in light of sequences from 16 beetles collected in seven sites in the country of South Africa (Evans et al., 2000) and a total of 31 beetles sequenced from populations in the United States (Evans et al., 2000 , and this study).

Individual beetles were collected directly from colonies, then were stored in $95 \%$ ethanol. Each beetle was dried separately in an incubator for $8+$ hours at $70^{\circ} \mathrm{C}$, after which a subset $(\mathrm{n}=316)$ of beetles was weighed. For DNA extraction, most samples $(\mathrm{n}=348)$ were pulverized using disposable grinders in a buffer of $0.01 \mathrm{M}$ Tris $\mathrm{pH} 7.8,0.005 \mathrm{M}$ EDTA, $0.5 \%$ SDS, and $1 \mathrm{mg} / \mathrm{mL}$ Proteinase $\mathrm{K}$, vortexed then incubated at $55^{\circ} \mathrm{C}$ for one hour. After incubation, potassium acetate was added to a final concentration of $1.2 \mathrm{M}$, samples were vortexed then incubated on ice for 30 minutes prior to centrifugation (10 minutes at $5000 \mathrm{rcf}$ ) to remove proteins. An equal volume of isopropanol was added to the supernatant to precipitate DNA, which was pelleted by centrifugation and washed twice 
Table I. Hive beetle collection sites and haplotypes by state and county Collection seasons: $*=1998,{ }^{\beta}=$ $1999, \Psi=2000$.

\begin{tabular}{lcccc}
\hline State & County & Number of apiaries & Sample size & Prop NA1 \\
\hline Florida & Indian River* & 2 & 151 & 0.37 \\
& Palm Beach $^{*}, \beta$ & 4 & 19 & 0.32 \\
Georgia & Volusia* $^{*}$ & 1 & 6 & 0.5 \\
& Chatham $^{*}$ & 2 & 71 & 0.07 \\
& Clinch $^{*}$ & 1 & 3 & 1 \\
& Lanier $^{*}$ & 1 & 3 & 1 \\
& Lowndes $^{\psi}$ & 1 & 6 & 0.83 \\
North Carolina & Pierce $^{*}$ & 2 & 9 & 0.56 \\
South Carolina & Scotland $^{*}, \beta$ & 2 & 12 & 0 \\
& Aiken* & 1 & 1 & 1 \\
& Charleston $^{*}, \beta, \Psi$ & 5 & 248 & 0.49 \\
& Kershaw $^{*}$ & 1 & 2 & 0 \\
\hline Total & Pickens $^{\beta}$ & 1 & 2 & 0.40 \\
\hline
\end{tabular}

more with $70 \% \mathrm{EtOH}$, before being dried and resuspended in $400 \mu \mathrm{L}$ of filtered water. A Chelex100 DNA extraction method (Walsh et al., 1991) was used with good success for the remaining samples. For this, $0.1 \mathrm{mg}$ from a dried and pulverized beetle was added to $100 \mu \mathrm{L} 5 \%$ Chelex100 (Bio-Rad) in filtered $\mathrm{H}_{2} \mathrm{O}$ then vortexed. The resulting slurry was incubated at $100{ }^{\circ} \mathrm{C}$ for 5 minutes, then was pelleted by centrifugation after which the supernatant was used in the polymerase chain reaction (PCR).

\subsection{PCR amplification and genotyping}

PCR was used to amplify a 1080 base-pair fragment of the mitochondrial cytochrome oxidase I (COI) gene, using oligonucleotide primers AT1904S (5'-GGTGGATCTTCAGTTGATTTAGC-3') and AT2953A (5'-TCAGCTGGGG GATAAAATTG-3') as described (Evans et al., 2000). In 14 beetles from Zimbabwe and the United States, cycle sequencing was carried out using the Big Dye 2.0 fluorescent end-terminator as per instructions (Applied Biosystems). Sequences were generated using the end primers shown above and internal primers AT2380S (5'-GACGTTGATACTCGAGCCTATT-3') and AT2519A (5'-GAAGTACTCCTGTTAATCCACC3'). Sequencing products were analyzed using an Applied Biosystems 377 automated sequencer. Previous surveys at the DNA sequence level revealed two distinct North American haplotypes for the COI gene. Haplotype NA2 (GenBank accession number AF227646) contains a sequence matching the recognition site of the restriction enzyme BstE11 (rec- ognition site: GGTCACC) at position 275 of the amplified product. Haplotype NA1 (GenBank accession number AF227645) is not cut at this site. PCR products from all beetles were exposed to enzyme BstE11 with the suggested buffer and temperature conditions (New England BioLabs) for two hours. Digestion products were separated by agarose gel electrophoresis ( $2 \%$ gel with ethidium bromide, in TAE buffer) and scored for polymorphism (Fig. 1). Positive controls were used in each set of digests to ensure restriction enzyme activity.

\subsection{Data analysis}

\subsubsection{Phylogenetic analyses}

DNA sequences for the 14 beetles described above and an additional 42 beetles from Evans et al. (2000) were aligned using the ClustalW algorithm and the software program Omiga 2.0 (Oxford

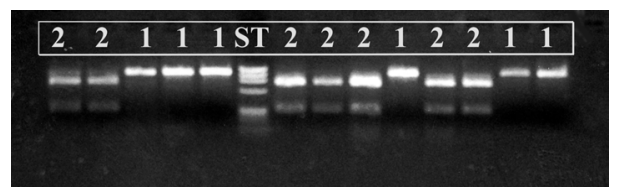

Figure 1. Restriction-enzyme profile for 13 beetles collected from Charleston County, South Carolina, showing the "cut" (NA2) and "uncut" (NA1) haplotypes at the cytochrome oxidase I gene, using the restriction enzyme $B s t \mathrm{E} 11$. ST $=$ DNA size standard IX (Boehringer-Mannheim). 
Molecular). This alignment showed no insertiondeletion events among the SHB samples. Samples then were compared using a maximum-parsimony algorithm (Swofford et al., 1996) and the analysis program PAUP 4b (Sinauer Associates). A distantly related nitidulid beetle (Colopterus sp.) was used to root the SHB samples.

\subsubsection{Haplotypic variation}

Nested analyses of variance (ANOVA) were used to estimate genetic structure at different geographic scales: Individual collection sites (apiaries) nested within counties, counties nested within states, and states. These analyses were carried out during a single season (1998) in Florida, Georgia, and South Carolina. Statewide haplotype frequencies were calculated using the weighted means of haplotypes from individual apiaries.

Collections from three apiaries, two in South Carolina (Johns Island and Charleston) and one in Florida (St. Lucie), allowed tests for season-to-season differences in haplotype frequency. Contingency analyses (G-test) were used to test each apiary separately for significant changes in haplotype frequency. For these analyses, "season" was defined as spanning from spring (March) until the next winter (February), since this period best matches the reproduction and dispersal of both bees and hive beetles.

To determine whether mtDNA haplotype was correlated with body size, the t-test statistic was used to compare mean body size by haplotype, for samples collected in 1998 from five sites in three states (South Carolina, Georgia and Florida). Tests were carried out for each collection separately.

\section{RESULTS}

\subsection{Relationships with African beetles}

All of the 56 hive beetles surveyed showed highly similar CO1 sequences, with $0.1 \%$ to $1.1 \%$ sequence divergence between haplotypes. The US beetles differed from each other at six nucleotide sites $(0.6 \%)$, a degree of difference similar to the average distance between African samples $(=6.3$ differences, $n=$ 72 pairs; Fig. 2). Haplotype NA1 differed from a South African haplotype (Grahamstown) by a single nucleotide, while NA2 differed by two nucleotides from the closest African haplotype (from Headlands, Zimbabwe).

\subsection{Geographic variation in the US}

Apiaries differed strongly in haplotype frequencies $($ Chi-square $=30.2, \mathrm{df}=12$,
$P<0.005$; Tab. I) during 1998, after accounting for regional (county and state-level) differences. Differences at the level of counties within states were insignificant. The only significant state-level difference in 1998 was that between Georgia and South Carolina, with samples from Georgia showing a higher frequency of haplotype NA2 $(0.93, \mathrm{n}=71)$ than samples collected in South Carolina $(0.42, \mathrm{n}=$ 170). Florida showed roughly equal haplotype frequencies in each of the five apiaries surveyed during this year (Tab. I).

\subsection{Year-to-year variation}

All six samples from the initial collections in Charleston, South Carolina, showed haplotype NA1, an unlikely event if these samples were chosen randomly with respect to the haplotype frequencies shown in later samples from the same apiaries (contingency analysis, Chi-square $=6.63, \mathrm{df}=2, P<0.05$ ) or with respect to those from the first collections in Florida, Georgia, and North Carolina (G-test, $P<0.001,0.001$, and 0.0001, respectively). This apiary showed a significant change in haplotype frequencies from 1998-2000 (Gtest, $\mathrm{df}=248$, Chi-square $=28, P<0.001)$. In 1998 and 1999, samples showed a slight bias toward haplotype NA1 (frequency NA1 = $0.58, \mathrm{n}=170$, and $0.57, \mathrm{n}=14$, respectively). Strikingly, samples collected in 2000 from this apiary showed a bias toward haplotype NA2 (NA1 frequency $=0.22, n=65$ ). There were no significant changes in haplotype frequency in the two other apiaries sampled across seasons. The sample-wide frequencies of NA1 and NA2 were unchanged over time (NA1/ total $=0.40,0.37$, and 0.35 in 1998, 1999, and 2000, respectively, for 533 samples).

\subsection{Variation in body size}

There was substantial variation in body size across beetles from different collections, ranging from an average weight of $3.61 \mathrm{mg}$ $(\mathrm{SE}=0.45, \mathrm{n}=12)$ in St. Lucie, Florida, to $7.46 \mathrm{mg}(\mathrm{SE}=0.33, \mathrm{n}=55)$ on Hutchinson Island, Georgia. This variation might reflect, in part, seasonal variation in body size for SHB. Beetles collected in February weighed $6.71 \mathrm{mg}$, on average ( $\mathrm{SE}=0.13, \mathrm{n}=196$ ), while beetles collected in May and July weighed $5.48 \mathrm{mg}(\mathrm{SE}=0.165, \mathrm{n}=120 ; t$-test 


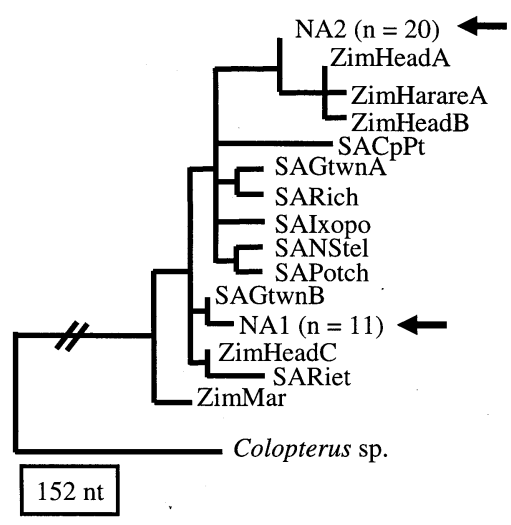

Figure 2. Maximum-parsimony phylogenetic tree showing relationships among two North American beetle haplotypes and beetles collected from South Africa and Zimbabwe. SA samples: Gtwn = Grahamstown, Rich $=$ Richmond, Nstel $=$ Niev Stellenbosch, Potch $=$ Potchefstroom, $\mathrm{CpPt}=\mathrm{Cape}$ Point. Zimbabwe samples: Har = Harare, Head = Headlands, Mar = Marondera. Representative samples from each distinct haplotype are shown. Sequences in Genbank as AF227645-AF227654 and AF522354-AF522358.

of the means $=5.86, \mathrm{df}=314, P<<0.0001)$. Site-by-site comparisons showed no biomass differences between the two haplotypes, for any of five collections for which both haplotypes were collected simultaneously (Tab. II).

\section{DISCUSSION}

Small hive beetles found in North America are indistinguishable using the $\mathrm{CO} 1$ gene from beetles native to two countries in southern Africa; Zimbabwe and South Africa. While not conclusive proof that these beetles came from southern Africa, as opposed to other regions on the continent, the extreme similarity between US and southern African samples $(0.1-0.2 \%$ sequence divergence) is well within the bounds expected for single populations (Funk, 1999). In fact, the sequence difference between two haplotypes now found in North America is similar to the average sequence difference between sympatric African samples.

Small hive beetle populations in North American apiaries show strong biases in mtDNA haplotype frequencies. We, therefore, can discount the hypothesis that mtDNA hap-
Table II. Body weights of hive beetles (mg) collected from independent collections at five sites, as a function of haplotype (NA1 or NA2). All beetles were collected in 1998 .

\begin{tabular}{lcc}
\hline Site & $\begin{array}{c}\text { NA1 } \\
\text { Mean (SE) }\end{array}$ & $\begin{array}{c}\text { NA2 } \\
\text { Mean }(\mathrm{SE})\end{array}$ \\
\hline Charleston, SC $(\mathrm{n}=7)$ & $5.44(1.26)$ & $5.66(0.80)$ \\
Chatham, GA $(\mathrm{n}=55)$ & $7.83(1.23)$ & $7.43(0.34)$ \\
Johns Island, SC $(\mathrm{n}=132)$ & $6.52(0.17)$ & $6.38(0.17)$ \\
St. Lucie, FL $(\mathrm{n}=12)$ & $3.43(0.71)$ & $3.54(0.70)$ \\
Vero Beach, FL $(\mathrm{n}=108)$ & $5.87(0.27)$ & $5.58(0.21)$ \\
\hline Total $(\mathrm{n}=316)$ & $6.23(0.15)$ & $6.26(0.15)$ \\
\hline
\end{tabular}

lotypes are randomly distributed in hive beetles, and can focus on the competing hypotheses that frequency differences indicate two or more separate introductions, ongoing selection at different sites, or genetic bottlenecks as beetles invade new sites (apiaries) in North America.

We used body mass as a surrogate for beetle fitness when comparing between the two haplotypes. Body mass is commonly used to test for differences in both competitive abilities and reproductive success in beetles and other insect species (Messina and Slade, 1999). We found no correlation between haplotype and adult body weight for five surveyed populations. Other measures, including direct estimates of changes in haplotype frequency within colonies, might provide a more precise estimate of fitness differences between beetles with the same haplotype. Nevertheless, the great overall differences in haplotype frequency (e.g., between Georgia (93\% NA2) and South Carolina (41\% NA2) would seem to require substantial fitness differences between bearers of these two haplotypes, differences that arguably would be apparent by indirect measures such as body weight. It will be difficult to distinguish any haplotype-associated effects on beetle fitness in future surveys, as the genes responsible for any such differences likely will show no long-term linkage with their mitochondrial haplotype.

We are left with two plausible hypotheses to explain haplotype frequency differences among sites. Significant differences at the apiary level suggest limited beetle movement between apiaries. Nevertheless, state-level 
differences in haplotype frequency, while not significant overall, were strongest in the earliest samples collected, and were significantly different between Georgia and South Carolina in 1998. These results support the hypothesis that these beetles had different invasion histories and are currently intermixing.

Further discrimination between these hypotheses will benefit from collections made from the earliest populations recorded in each state. Especially useful will be earlier samples from Georgia and Florida, states whose earliest beetle populations have not yet been genotyped. These states show a modern-day bias toward haplotype NA2, a trend that was in place in the first beetles assayed in 1998. Beetles were first collected in Georgia in 1997. Should these beetles carry haplotype NA2 exclusively, that would provide evidence for an initial population that was distinct from the first beetles found in South Carolina, all of which showed haplotype NA1. Using modern samples, additional surveys across adjacent apiaries will determine the extent to which dispersal bottlenecks can explain the observed differences in haplotype frequencies. For example, are current beetle populations in North Carolina still biased toward haplotype NA2? In addition, the increasing number of states to which these beetles have migrated offer additional opportunities to infer the population-genetic dynamics of invasion. As one practical outcome of such studies, estimates of the number of female beetles "needed" to colonize apiaries should help predict the rate of spread of these beetles to new apiaries, thereby informing strategies for their control.

As hive beetles spread in North America, regional differences in haplotype frequencies should erode, barring strong bottlenecks each time beetles invade a new apiary or region. Ultimately, beetle populations should reflect current populations in Florida, where the two haplotypes are mixed across all sites, apparently at equal frequencies. Nevertheless, it might be possible in the short term to infer whether newly discovered beetle populations are derived from sources with biased haplotype frequencies (e.g., parts of South Carolina versus Georgia).

The limited number of haplotypes in the North America samples (2 haplotypes) com- pared to the diversity found in a sample of similar size from southern Africa (where 13 haplotypes have been described; Evans et al., 2000; this paper), suggests that any new introductions of hive beetles will be distinguishable from those currently found in North America. This fact might be used by researchers and regulatory agencies to pinpoint sources of any future beetle introductions to the Americas and elsewhere.

\section{ACKNOWLEDGEMENTS}

We thank J. Ambrose, B. Carter, P. Harvey, D. Hopkins, L. Motes, B. Smith, E. Stoddard, $\mathrm{S}$. Taber, and W. Weatherford for collecting beetles in the US, and M. Allsopp, D. Swart, and M. Schmolke for collecting African beetles. D. Pham and D. Lopez helped with genetic analyses and T. Brown provided comments on the manuscript. Use of commercial names does not imply endorsement by the USDA over other products not mentioned.

Résumé - Suivre la trace d'un parasite d'Abeille qui gagne du terrain : variation de l'ADN mitochondrial chez le Petit Coléoptère des ruches en Amérique du Nord. Le Petit Coléoptère des ruches (PCR), Aethina tumida Murray (Coleoptera, Nitidulidae), se nourrit de pollen et de miel et détruit les rayons des colonies d'abeilles domestiques (Apis mellifera L.). Ces PCRs, originaires d'Afrique, ont été trouvés pour la première fois aux États-Unis en 1996. En six ans ils se sont répandus dans au moins 25 états des États-Unis, provoquant des pertes de colonies dans toute la région du sud-est. Dans ce travail nous avons utilisé la variation du gène mitochondrial COI pour décrire les populations de PCRs. Les séquences de l'ADN mitochondrial placent les populations de PCRs des États-Unis au sein d'un clade de coléoptères d'Afrique du Sud. Il est intéressant de noter que deux haplotypes distincts existent aux États-Unis. Une récolte de 539 PCRs dans 26 ruchers répartis en Floride, Géorgie, Caroline du Nord et du Sud (Tab. I) a montré des répartitions irrégulières de ces deux haplotypes dans la région du sud est des États-Unis. Les PCRs des premières récoltes faites en Caroline du Sud présentaient une fréquence élevée de l'haplotype NA1, haplotype généralement rare en Floride et en Géorgie et absent de l'échantillon de Caroline du Nord. Les récoltes récentes en Caroline du Sud ressemblent plus à celles des autres états. La taille corporelle des PCRs n'est pas corrélée à l'haplotype (Tab. II), ce qui suggère que la fréquence des haplotypes ne reflète pas les pressions de sélection sur les différences covariantes dans les génomes de ces PCRs. Nous discutons des implications qu'ont ces résultats dans les problèmes suivants : déduction du nombre d'introductions séparées de ces PCRs aux 
États-Unis, identification de nouvelles introductions et estimation de la dynamique de migration des PCRs au fur et à mesure qu'il étendent leur aire de répartition dans le Nouveau Monde. Les haplotypes des coléoptères des ruches aux États-Unis indiquent, soit deux introductions séparées soit des effets de dérive suivis d'une dispersion extrêmement limitée.

Apis mellifera / Aethina tumida / ADNmt / parasite / dispersion population / migration

Zusammenfassung - Rückverfolgung der Einschleppung eines Schädlings der Honigbienen: Mitochondriale DNA Variation beim kleinen Beutenkäfer in Nord Amerika. Der kleine Beutenkäfer (Aethina tumida Murray) ernährt sich von Pollen und Honig und zerstört dabei die Waben in den Völkern der Honigbienen. Diese Käfer, die aus Afrika stammen, wurden 1996 zum ersten Mal in den USA entdeckt. Im Jahr 2002 hatten sich die Beutenkäfer in mindestens 25 Staaten der USA verbreitet und $\mathrm{zu}$ Verlusten von Völkern im gesamten südöstlichen Gebiet geführt. Mitochondriale DNA Sequenzen ordnen die Populationen der US Beutenkäfer einem Zweig aus dem südlichen Afrika zu. Es ist interessant, dass es zwei distinkte Haplotypen in den USA gibt. Eine Sammlung von 539 Beutenkäfern wies eine ungleichmäßige Verteilung der beiden Haplotypen in den südöstlichen USA auf. Bei der ersten Sammlung in South Carolina gab es überwiegend Käfer vom Haplotyp NA1, während dieser Haplotyp in Florida und Georgia nur selten vorkam. In den Proben von North Carolina wurde er überhaupt nicht gefunden. Dagegen sind neue Proben von South Carolina ähnlich wie die Befunde der anderen Staaten. Die Körpergröße der Käfer korrelierte nicht mit den unterschiedlichen Haplotypen (Tab. II). Das lässt vermuten, dass die Unterschiede in der Frequenz der Haplotypen nicht einem Selektionsdruck für covariable Unterschiede im Genom dieser Käfer unterworfen ist. Wir diskutieren, ob die Ergebnisse für eine Klärung über die Häufigkeit von unabhängigen Einführungen der Beutenkäfer in die USA, für die Erkennung von neuen Importen und für die Einschätzung der Dynamik bei der Verbreitung in der Neuen Welt herangezogen werden können. Die Haplotypen der Beutenkäfer in den USA weisen entweder auf 2 unterschiedliche Einschleppungen hin oder auf Auswirkungen eines Drifts mit nachfolgender stark limitierter Verteilung.

\section{Apis mellifera / mtDNA / eingeschleppter Schädling / Nitidulidae}

\section{REFERENCES}

Anderson D.L., Trueman J.W.H. (2000) Varroa jacobsoni (Acari: Varroidae) is more than one species, Exp. Appl. Acarol. 24, 165-189.

Buys B. (1975) A survey of honeybee pests in South Afric, Proc. I Congr. Entomol. Soc. South. Afr., Stellenbosch, pp. 185-189.

de Guzman L.I., Rinderer T.E. (1999) Identification and comparison of Varroa species infesting honey bees, Apidologie 30, 85-95.

Elzen P.J., Baxter J.R., Westervelt D., Randall C., Delaplane K.S., Cutts L., Wilson W.T. (1999) Field control and biology studies of a new pest species, Aethina tumida Murray (Coleoptera: Nitidulidae), attacking European honey bees in the Western Hemisphere, Apidologie 30, 361366 .

Evans J.D., Pettis J.S., Shimanuki H. (2000) Mitochondrial DNA relationships in an emergent pest of honey bees: Aethina tumida (Coleoptera: Nitidulidae) from the United States and Africa, Ann. Entomol. Soc. Am. 93, 415-420.

Funk D. (1999) Molecular systematics of cytochrome oxidase I and 16S from Neochlamisus leaf beetles and the importance of sampling, Mol. Biol. Evol. $16,67-82$.

Hood W. (2000) Overview of the small hive beetle, Aethina tumida, in North America, Bee World 81, 129-137.

Messina F.J., Slade A.F. (1999) Expression of a lifehistory trade-off in a seed beetle depends on environmental context, Physiol. Entomol. 24, 358-363.

Pettis J., Shimanuki H. (2000) Observations on the small hive beetle, Aethina tumida Murray, in the United States, Am. Bee J. 140, 152-155.

Roberts E. (1979) A survey of beekeeping in Uganda, Bee World 52, 57-67.

Sheppard W.S., Rinderer T., Garnery L., Shimanuki H. (1999) Analysis of Africanized honey bee mitochondrial DNA reveals further diversity of origin, Genet. Mol. Biol. 22, 73-75.

Swofford D., Olsen G., Waddell P., Hillis D. (1996) Phylogeny reconstruction, in: Hillis D.M., Moritz C., Mable B.K. (Eds.), Molecular systematics, Sinauer Associates, Sunderland, pp. 407-514.

Walsh P., Metzger D., Higuchi R. (1991) Chelex 100 as a medium for simple extraction of DNA for PCR-based typing from forensic material, Biotechniques 10, 506-510. 